\title{
Menyinergikan Aturan Prudensial Dan Aturan Kepatuhan Syariah Pada Perbankan Syariah Di Indonesia
}

\author{
Agus Triyanta \\ Fakultas Hukum Universitas Islam Indonesia \\ Jln. Tamansiswa No. 158 Yogyakarta \\ agustriyanta@uii.ac.id dan triyantaagus@yahoo.com
}

Received: 13 Desember 2018; Accepted: 8 Februari 2019; Published: 24 April 2019

DOI: 10.20885/iustum.vol26.iss1.art6

\begin{abstract}
Besides being generally bound by prudential principles in banking regulations, Islamic banking in Indonesia is also bound by sharia principles. In reality, there are several contradictions between these two jurisdictions (conventional banking and Islamic banking). This article aims to discuss why the contradictions between these two jurisdictions can occur. Furthermore, how the possibilities are to make harmony or adjustment among the various different elements, so that these two different jurisdictions can synergistically play a role in driving the development of Islamic banking in Indonesia. The research method in this article is normative legal research with a qualitative analysis model. The conclusion of this article showed that the set of regulations related to the prudential principle of banking in two banking models (conventional and sharia) in fact were the same. It was because this regulation related to banking prudential was originally designed for conventional banking, and, when applied to Islamic banking, various adjustments were needed, for example in the collateral case. This article recommends that sharia-based prudential principles should be immediately integrated into the regulation of banking prudential principles in general to prevent any problems arose from the application of Islamic banking.
\end{abstract}

Keywords: Synergy; prudential; sharia compliance; sharia banking

Absrak

Selain terikat dengan prinsip-prinsip prudensial dalam regulasi perbankan secara umum, Perbankan Islam di Indonesia, juga terikat dengan prinsip-prinsip syariah. Dalam kenyataannya, terdapat beberapa kontradiksi antara dua wilayah hukum ini (perbankan konvensional dan perbankan syariah). Artikel ini bermaksud untuk mendiskusikan mengapa kontradiksi antara dua wilayah hukum ini terjadi. Selanjutnya, bagaimanakah kemungkinan untuk dilakukannya harmonisasi atau penyesuaian di antara berbagai elemen yang berbeda tersebut, sehingga dua wilayah hukum yang berbeda ini dapat secara sinergis berperan dalam mendorong perkembangan perbankan syariah di Indonesia. Metode penelitian dalam artikel ini adalah penelitian hukum normatif dengan model analisis kualitatif. Kesimpulan artikel ini adalah bahwa perangkat regulasi terkait prinsip prudensial perbankan dalam dua model perbankan (konvensional dan syariah) ternyata sama. Dikarenakan regulasi terkait prudensial perbankan ini semula dirancang untuk perbankan konvensional, maka ketika diterapkan untuk perbankan syariah, diperlukan berbagai penyesuaian, misalnya dalam masalah kolateral atau jaminan. Artikel ini merekomendasikan bahwa prinsip-prinsip prudensial yang berbasis syariah semestinya segera diintegrasikan dalam regulasi prinsip prudensial perbankan secara umum agar dalam aplikasinya dalam perbankan syariah tidak menimbulkan masalah.

Kata-kata Kunci: Sinergi; prudensial; kepatuhan syariah; perbankan syariah 


\section{Pendahuluan}

Perbankan syariah muncul dan berkembang sebagai sebuah entitas baru dalam dunia bisnis atau transaksi keuangan. ${ }^{1}$ Latar belakang kemunculannya sudah pasti dikarenakan ada berbagai aspek mendasar. Sebagai sebuah sistem yang bertekad menjadi sebuah antitesis dari rezim riba, sebuah sistem bisnis keuangan yang sudah menjadi arus utama selama ratusan tahun, tentu kehadiran perbankan syariah memiliki berbagai alasan yang fundamental, utamanya dari segi prisip-prinsip syariah Islam. ${ }^{2}$

Namun, di sisi yang lain, sebagai sebuah entitas bisnis, perbankan syariah tidak mungkin lepas dari berbagai tuntutan dan kepentingan yang bersifat ekonomis, atau lebih khususnya adalah kepentingan profit. Masalah ini bukan hal yang sederhana, karena memang pada dasarnya, atas dasar kepentingan yang seperti itulah setiap lembaga bisnis lahir dan berkembang. Bukankah bank syariah sebagai entitas bisnis juga memiliki banyak pimpinan dan karyawan, yang mereka semua harus diberikan gaji dan remunerasi yang memadai. Juga, pelayanan kepada semua stakeholders harus dilakukan dengan cara dan instrumen yang selalu aktual dan mampu merespon perkembangan masyarakat dan teknologi yang berkaitan dengan keuangan, yang itu semua akan dapat dengan mudah dipenuhi jika ada profit.

Masalah rumit terkait dengan perbankan syariah ini diantaranya adalah bahwa dalam kenyataannya, tuntutan untuk selalu memenuhi aturan terkait prudensial tidak selamanya sejalan dengan tuntutan akan kepatuhan terhadap prinsip syariah, misalnya saja penerapan jaminan yang sangat ketat. Atau sebaliknya, berbagai prinsip syariah terkait masalah transaksi dan layanan perbankan adakalanya tidak sejalan dengan aturan terkait dengan prudensial, misalnya anjuran untuk memberikan penangguhan bagi orang yang berhutang sampai mendapatkan kemudahan untuk membayarnya. Terdapat berbagai

\footnotetext{
1 Perbankan Islam baru muncul pada dekade 70 an, meskipun berbagai eksperiman sudah dimulai pada akhir paruh pertama abad 20, dan yang cukup terkenal adalah eksperimen dana haji di Malaysia tahun 1940-an. Namun, eksperimen di Mit Ghamr lah yang dipandang menjadi ekperimen yang berhasil dan karenanya dipandang sebagai awal kelaiharan bank syariah di dunia. (Sudin, ) Sudin Haron dan Bala Shanmugam, Islamic Banking System, Concepts and Applications, Pelanduk Publications, Selangor, 1997, hlm. 5 dan 15.

2 Agus Triyanta, Hukum Perbankan Syariab: Regulasi, Implementasi dan Formulasi Kepatuhannya Terhadap PrinsipPrinsip Islam, Malang, Setara Press 2016, hlm. 3
} 
persoalan dilematis yang mengharuskan untuk melakukan pilihan-pilihan yang tidak sederhana. Karena itulah maka sangat menarik untuk dianalisa lebih lanjut dalam aspek apa sajakah ketidaksejajaran itu terjadi, serta bagaimanakah upaya yang harus dilakukan agar antara kedua tuntutan itu dapat diimplementasikan secara sinergis.

\section{Rumusan Masalah}

Berdasarkan uraian dalam pendahuluan tersebut, maka gambaran dari permasalahan yang dipertanyakan dalam konteks masalah ini semakin jelas. Secara rinci masalah yang dimaksud dapat dirumuskan sebagai berikut, pertama, bagaimanakah regulasi dan implementsi dari prinsip-prinsip prudensial dalam perbankan syariah? Kedua, bagaimanakah upaya untuk menyinergikan ketentuanketentuan aspek prudensial dan prinsip-prinsip syariah dalam perbankan syariah di Indonesia?

\section{Tujuan Penelitian}

Berdasarkan rumusan masalah yang tertera di atas, ada beberapa tujuan dari penelitian ini. Secara rinci, tujuannya adalah sebagai berikut pertama, untuk menggali secara komprehensif regulasi dan implementsi dari prinsip-prinsip prudensial dalam perbankan syariah. Kedua, untuk merumuskan upaya untuk menyinergikan ketentuan-ketentuan aspek prudensial dan prinsip- prinsip syariah dalam perbankan syariah di Indonesia.

\section{Metode Penelitian}

Jenis penelitian ini adalah penelitian normatif atau penelitian hukum doktriner. Sehingga bahan hukum dari penelitian ini terdiri dari; 1) Bahan hukum primer : bahan-bahan hukum yang mempunyai kekuatan hukum mengikat yang meliputi: undang-undang, peraturan-peraturan, Al-Qur'an, al-Sunnah, serta fatwa Dewan Syariah Nasional di bidang perbankan syariah. 2) Bahan hukum sekunder berupa literatur, jurnal dan data elektronik serta, 3) Bahan-bahan hukum tersier berupa kamus dan ensiklopedi. Cara pengumpulan bahan hukum dilakukan melalui;1) Studi pustaka, yakni dengan mengkaji berbagai peraturan atau literatur yang berhubungan dengan permasalahan yang akan diteliti, dan, 2) Studi 
dokumen, yakni dengan mengkaji berbagai dokumen yang terkait dengan permasalahan yang akan diteliti.

Analisis hasil penelitian dilakukan dengan cara deskriptif-analitis. Data yang terkumpul dari studi kepustakaan, dianalisis dengan metode kualitatif, yaitu datadata yang diperoleh dari hasil penelitian dikelompokan dan dipilih, kemudian dihubungkan dengan masalah yang akan diteliti, sehingga dapat menjawab perumusan masalah yang ada. Data dihimpun dengan pengamatan yang seksama, meliputi analisis dokumen dan catatan-catatan. Penelitian kualitatif ini dengan mempergunakan cara berpikir secara induktif, yaitu pola pikir dan cara pengambilan kesimpulan yang dimulai dari suatu gejala dan fakta satu persatu, yang kemudian dapat diambil suatu generalisasi (ketentuan umum) sebagai suatu kesimpulan.

\section{Hasil Penelitian dan Pembahasan}

\section{Kerangka Hukum Prinsip Kehati-Hatian (Asas Prudensial) dan Implementasinya dalam Perbankan Syariah}

Pengaturan perbankan syariah di Indonesia dapat dikatakan sudah cukup baik dan detail. Bahkan dalam beberapa aspek, pengaturan di Indonesia lebih baik jika dibandingkan dengan pengaturan di berbagai negara lain. ${ }^{3}$ Saat ini, perbankan syariah sudah memiliki aturan yang relatif lengkap, karena di samping mendapatkan pengaturan secara parsial pada Undang-Undang No. 7 Tahun 1992 tentang Perbankan, serta Undang-Undang No. 10 Tahun 1998 tentang Perbankan yang merupakan amandemen dari Undang-Undang No. 7 Tahun 1992, juga sudah memiliki aturan lex spesialis, ialah Undang-Undang Republik Indonesia No. 21 Tahun 2008 tentang Perbankan Syariah, ${ }^{4}$ yang undang-undang ini secara khusus mengatur tentang berbagai aspek terkait dengan Perbankan Syariah di Indonesia.

Adanya Undang-Undang yang secara khusus mengatur perbankan syariah, berbagai aspek yang terkait dengan perbankan syariah diperhatikan secara serius, karena tingginya posisi undang-undang dalam hirearki hukum dan perundang-

${ }^{3}$ Misalnya di Singapura, Dubai (UEA), tidak memiliki pengaturan tentang pengawasan syariah secara ketat. Lihat, Rusni Hassan, et al, A Comparative Analysis on Shariah Governance In Islamic Banking Accross Judisdiction, Institute for Shariah Research Academy (ISRA), Malaysia, 2013, hlm. 1-2

${ }^{4}$ Undang-Undang No. 21 Tahun 2008 tentang Perbankan Syariah merupakan salah satu undang-ungan yang terlama dalam hal proses kelahirannya, tidak kurang dari 5 tahun lamanya, bahkan terbitnya kalah cepat dibandingkan dengan Undang-Undang No. 19 Tahun 2008 tentang Surat Berharga Syariah Negara (SBSN) yang sebelumnya tidak diharapkan setinggi dengan harapan terhadap Undang-Undang Perbankan Syariah. 
undangan di Indonesia. Berbagai aspek yang dimaksud meliputi pengaturan tentang perizinan, kriteria dan macam-macam produk perbankan syariah, tata kelola penyelenggaraan perbankan syariah, serta berkaitan dengan asas kesehatan bank syariah, atau yang lebih dikenal dengan asas prudensial. Terkait dengan aspek prudensial ini, perbankan syariah, sebagai sub sistem dari perbankan nasional, tidak mendapatkan pengecualian atau perlakuan khusus. Artinya, perbankan syariah harus memenuhi atau tunduk terhadap ketentuan terkait prinsip kehati-hatian ini.

Prinsip prudensial pebankan, dalam Black's Law Dictionary dapat didefiniskan sebagai a term that means to use good judgment, be wise, sensible and reasonably cautious. ${ }^{5}$ Maksud dari pengertian tersebut adalah pengambilan putusan yang baik, dengan cara yang bijaksana, dengan langkah penuh kehati-hatian yang dapat dipahami dan rasional dalam mengelola bisnis perbankan. Prinsip ini, secara umum kemudian dikenal dengan prinsip kehati-hatian. Perbankan syariah, dalam hal prinsip kehatihatian ini sebenarnya tidak menunjukkan perbedaan jika dibandingkan dengan perbankan konvensional. Untuk mempermudah pembahasan dalam artikel ini, penulis akan mengklasifikasikan diskusi dalam tiga aspek, yaitu, pembiayaan, layanan nasabah, dan yang terkakhir adalah pengelolaan dana.

Pertama, dalam pembiayaan. Sebagaimana yang telah menjadi pengetahuan umum, dalam perbankan syariah tidak ada istilah kredit, namun semua penyebutan terkait dengan pengucuran dana kepada nasabah dinyatakan dengan kata pembiayaan. ${ }^{6}$ Maka, dalam pembiayaan ini juga harus tunduk pada prinsip kehatihatian. Hal ini secara jelas tercantum dalam Undang-Undang No. 21 Tahun 2008 tentang Perbankan Syariah. Dalam Pasal 23 ayat (2) disebutkan: “Untuk memperoleh keyakinan sebagaimana dimaksud pada ayat (1), Bank Syariah dan/atau UUS wajib melakukan penilaian yang saksama terhadap watak, kemampuan, modal, agunan, dan prospek usaha dari calon Nasabah Penerima Fasilitas." ${ }^{\prime 7}$

\footnotetext{
5 The Law Dictionary, Featuring Black's Law Dictionary Free Online Legal Dictionary 2nd Ed, dalam https://thelawdictionary.org/prudent/ diakses pada 25 April 2018.

${ }^{6}$ Digunakannya kata "pembiayaan" sebagai ganti dari istilah kredit dikarenakan dalam pengertian umum terkait kredit, menyatakan bahwa kredit adalah pembiayaan dengan basis perjanjian utang-piutang dengan kompensasi bunga. Lihat; Undang-Undang No. 10 Tahun 1998 tentang Perbankan, Pasal 1 ayat (11).

${ }^{7}$ Undang-Undang No. 21 Tahun 2008 tentang Perbankan Syariah Pasal 23 ayat (2)
} 
Secara teoretis, inilah yang kemudian dikenal dengan prinsip 5C. Lembaga keuangan (bank) harus mematuhi prinsip-prinsip kehati-hatian, yang utamanya dicerminakan dengan indikator 5C (character, capital, capacity, collateral, dan condition of economic). ${ }^{8}$ Character bermaksud kepribadian dari calon nasabah, sifat dan kebiasaan yang dimilikinya, utamanya terkait dengan urusan-urusan keuangan. Capital berarti adalah permodalan yang dimiliki oleh nasabah dalam melakukan suatu usaha ekonomi atau pengadaan suatu aset. Bahwa jika bank akan memberikan pembiayaan, maka harus dilihat apakah permodalan yang dimiliki atau yang sudah ada mencukupi jika kemudian diberikan pembiayaan sehingga usaha akan berjalan dengan baik dan sukses. Capacity adalah kemampuan dari calon nasabah untuk membayar kredit atau pembiayaan yang diberikan kepadanya. Adapun collateral adalah adanya jaminan yang dimiliki oleh nasabah yang gunanya adalah untuk mengantisipasi jika nasabah kelak tidak dapat memenuhi kewajibannya. Terakhir, condition of economic adalah kondisi ekonomi yang ada atau terjadi pada saat pembiayaan diberikan. Dapat juga dimaknasi sebagai trend dari kondisi ekonomi yang akan datang apakah kondisi yang akan terjadi mendukung ataukah tidak dengan keperluan ekonomi yang akan dipenuhi dengan pembiayaan tersebut. ${ }^{9}$ Dengan adanya ketentuan terkait kehati-hatian tersebut, maka bank akan dapat menjaga dari kemungkinan atau ancaman gagal bayar karena berbagai faktor yang terjadi.

Berdasarkan referensi yang ada, sebenarnya prinsip-prinsip kehati-hatian dari bank bukan hanya berupa perangkat 5Cdi atas. Selain 5C tersebut, terdapat instrumen lain, ialah 5P, people (orang, dalam hal ini adalah nasabah), purpose (tujuan), payment (pembayaran), protection (perlindungan) dan porspective (plan) (tujuan yang dikehendaki). ${ }^{10}$ Instrumen yan lain lagi dan cukup penting untuk disebut adalah CAMPARI, yakni; Character (sifat, dalam hal ini adalah sifat-sifat nasabah), ability to pay (kemampuan untuk membayar), margin of finance (margin pebiayaan), purpose (maksud atau tujuan), amount (jumlah pembiayaan), repayment

8 Abbadi, M Suleman dan Karsh, Sharif M. Abu, 'Methods of Evaluating Credit Risk used by Commercial Banks in Palestine,' International Research Journal of Finance and Economics, Issue 111 July, 2013, hlm. 151. Khusus dalam poin 5 c, Abbadi mengutip dari Peavlere Rosmary (2013)

9 Pemaknaan ini dapat dipahami dari: 5 C's of Credit Analysis, dalam situs resmi Minority Business Development Agency, US Department of Commerce, ialah, https://www.mbda.gov/news/blog/2010/08/5-cscredit-analysis akses pada 2 November 2018.

${ }^{10}$ Ibid 
terms (syarat pembayaran ulang), dan insurance (asuransi). ${ }^{11}$ Namun, dalam artikel ini, instrumen $5 \mathrm{C}$ adalah yang dijadikan acuan, sebagaimana hal ini juga yang telah disebutkan dalam regulasi yang ada di Indonesia sebagaimana disebut di atas.

Kedua, dalam layanan nasabah. Meski tidak secara langsung terkait dengan pembiayaan yang akan dilakukan, secara umum dalam melayani nasabah, bank harus menggunakan ketentuan Uji Tuntas Lanjut (Enhanced Due Diligence) ${ }^{12}$ atau yang dahulu dikenal dengan KYC, yang merupakan singkatan dari Know Your Customer, yang artinya "kenalilah pelanggan kamu." Ketentuan ini adalah suatu langkah yang harus ditempuh oleh pihak bank ketika berhadapan dengan nasabah, terutama nasabah yang masih baru yang belum banyak dikenal dengan berbagai layanan sebelumnya di bank terkait.

Alasan mengapa nasabah perlu dikenal dengan baik adalah bahwa perbankan harus terhindar dari orang-orang atau pihak-pihak yang akan bermaksud untuk melakukan tindakan jahat. Melalui mengenal nasabah dengan baik, berbagai kemungkinan buruk dapat dicegah. Ketentuan atau prinsip KYC ini pada awalnya dikeluarkan oleh Bank Indonesia tahun 2001 ketika upaya mengantisipasi kejahatan pencucian uang (money laundering), yakni dengan dikeluarkannya Peraturan Bank Indonesia Nomor: 3/10/PBI/2001tentang Penerapan Prinsip Mengenal Nasabah (Know Your Customer Principles). ${ }^{13}$

Seiring dengan berbagai perkembangan dan tuntutan dunia bisnis dan transaksi keuangan, prinsip ini sudah diganti menjadi Uji Tuntas Nasabah (Customer Due Diligence) atau CDD. Jika memang diperlukan, setelah CDD dapat ditingkatkan menjadi Uji Tuntas Lanjut (Enhanced Due Diligence) yang selanjutnya disingkat EDD adalah tindakan yang dilakukan Penyedia Jasa Keuangan terhadap calon nasabah yang berisiko tinggi. ${ }^{14}$ Meski demikian, substansi KYC tetap menjadi

11 Ibid

${ }^{12} \mathrm{Hal}$ ini dikarenakan terkait dengan upaya mengantisipasi kejahatan terkait money laundering dan terorisme, yang telah diatur dalam Bab I pasal 1 ayat (11) dari Peraturan Otoritas Jasa Keuangan Nomor 12/POJK.01/2017 Tentang Penerapan Program Anti Pencucian Uang dan Pencegahan Pendanaan Terorisme di Sektor Jasa Keuangan.

13 Peraturan Bank Indonesia Nomor : 3/10/PBI/2001Tentang Penerapan Prinsip Mengenal Nasabah (Know Your Customer Principles), khususnya Pasal 2 dan 3. Peraturan ini menegaskan bahwa KYC adalah kewajiban dari bank, dan Direksi bank wajib menjalankan hal ini dengan menerapkan prosedur yang dibuat dalam rangkan implementasi dari KYC.

14 Bab I Pasal 1 ayat (11) dari Peraturan Otoritas Jasa Keuangan Nomor 12/POJK.01/2017 tentang Penerapan Program Anti Pencucian Uang dan Pencegahan Pendanaan Terorisme di Sektor Jasa Keuangan. 
bagian dari prinsip EDD tersebut, karenanya tindakan dalam konteks dan kepentingan KYC tetap dilakukan.

Undang-undang dengan tegas menyatakan, "Bank Syariah dan UUS wajib menerapkan manajemen risiko, prinsip mengenal nasabah, dan perlindungan nasabah." 15 Sehingga, tidak ada alasan bagi pihak bank untuk tidak menelusuri, dalam batas-batas tertentu, terkait dengan latar belakang dan berbagai informasi dari nasabah. Tentu saja, dalam proses ini, masing-masing bank memiliki metode yang dinilai paling proprosional menurut tata kelola yang dimiliki bank yang bersangkutan. Namun, suatu hal yang sangat sulit dihindari adalah adanya kesan kecurigaan yang dikembangkan oleh pihak perbankan. Karena memang sangat sulit untuk di satu sisi berusaha menggali informasi personal nasabah dengan tanpa ada rasa keingintahuan pada hal-hal yang negatif. Dalam tingkat tertentu, persangkaan-persangkaan akan senantiasa sengaja dikembangkan.

Memang, jika dilihat dari konteks di mana popularitas KYC ini mengemuka adalah semakin merebaknya kejahatan keuangan dengan memanfaatkan fasilitas perbankan. Konsep KYC ini semakin menjadi prosedur yang sangat dikenal semenjak kejahatan money laundering (kejahatan pencucian uang) menjadi perhatian besar kalangan perbankan. Dengan tingginya kejahatan keuangan, seperti korupsi, penyelundupan dan pengedaran narkoba, human trafickcing, serta berbagai akumulasi uang haram lainnya di berbagai negara, maka kemudian perbankan harus melakukan berbagai tindakan prevensi untuk ikut melacak alur dari penyaluran uang haram tersebut.

Secara teoretis, KYC ini agaknya mirip seperti kegiatan intelijen pada operasional perbankan, karena KYC ini mengamanatkan agar bank mendapat informasi sejelas mungkin tentang nasabah dengan segala latar belakangnya, atau jika terkait dengan uang, harus tahu dari mana sumber keuangan dan sekaligus ke

Customer Due Diligence yang disingkat CDD adalah kegiatan berupa identifikasi, verifikasi, dan pemantauan yang dilakukan oleh PJK untuk memastikan transaksi sesuai dengan profil, karakteristik, dan/atau pola transaksi Calon Nasabah, Nasabah, atau WIC (Walk in Customer). Sedangkan Uji Tuntas Lanjut (Enhanced Due Diligence) yang disingkat EDD adalah tindakan CDD yang lebih mendalam yang dilakukan Penyedia Jasa Keuangan terhadap Calon Nasabah, WIC, atau Nasabah, yang berisiko tinggi.

15 UU No. 21 Tahun 2008 Pasal 38 ayat (1). Bunyi dari ayat tersebut sebenarnya menyiratkan bahwa meskipun KYC sudah diganti menjadi CDD, namun secara substansial memang pada prinsipnya semangatnya adalah sama, ialah mencari informasi terkait nasabah dengan berbagai cara yang dimungkinkan. 
mana aliran uang itu ditujukan, terlebih lagi jika uang tersebut dalam jumlah yang besarnya di atas rata-rata jumlah uang nasabah.

KYC juga antara lain telah mematahkan tradisi lama, yang sudah puluhan atau bahkan ratusan tahun melekat dalam layanan perbankan, ialah apa yang diterminologikan dengan 'rahasia perbankan' atau bank secrecy. Atas doktrin rahasia perbankan ini, maka berbagai informasi terkait nasabah akan dijaga dengan sangat rapat oleh pihak perbankan. Sebegitu kuatnya rahasia nasabah itu akan dijaga, sampai ada negara di dunia ini yang sangat dikenal sebagai tempat di mana rahasia perbankan sangat dijunjung tinggi, sehingga keamanan uangnya sangat terlindungi, ialah di Swiss atau Switzerland. Namun, baru pada awal-awal abad inilah rahasia perbankan di negara tersebut harus runtuh karena kuat dan derasnya tekanan dari duia internasional agar bank-bank di Swiss juga dapat bekerjasama dalam menanggulangi tindakan money laundering, yakni dengan cara bank tidak boleh lagi merahasiakan nasabah dan aliran uang yang terkait dengan tindakan kejahatan di suatu negara. ${ }^{16}$

Ketiga, dalam pengelolaan dana, harus mengikuti ketentuan terkait dengan FDR dan NPF. Jika dalam perbankan konvensional dikenal adanya LDR, singkatan dari liquid to deposit ratio, serta NPL, singkatan dari non performing loan, maka hal yang nyaris sama namun dengan istilah berbeda juga berlaku pada perbankan syariah. ${ }^{17}$ FDR dalam bank syariah singkatan dari financing to deposit ratio, serta NPF singkatan dari non performing financing. Ini semua adalah pengukuran tentang kesehatan perbankan derdasarkan besarnya uang yang dikeluarkan sebagai pembiayaan dibandingakan berbagai aspek, setidaknya terhadap uang (modal) atau tingkatan pembiayaan yang tidak lancar.

\footnotetext{
16 Runtuhnya konsep rahasia perbankan di tingkat dunis ditandai dengan dibukanya informasi terkait rekening simpanan dari nasabah yang disimpan di perbankan Swiss (Switzerland). Di mana pada bulan Agustus 2009 negara ini melakukan amandemen perjanjian pajak dengan Perancis sebagai negara yang warga negaranya memiliki rekening di perbankan Swiss. Ini telah menandai berakhirnya berakhirnya era rahasisa perbankan. Niels Johannesen dan Gabriel Zucman, “The End Of Bank Secrecy? An Evaluation Of The G20 Tax Haven Crackdown”, American Economic Journal: Economic Policy 2014, 6(1): 65 - 91

17 Perbedaan istilah ini juga sebagai konsekuensi dengan penyelarasan istilah dalam produk perbankan syariah. Penjelasan kriteria prudensial; batas maksimum kredit, LDR, modal minimum, CAR, GWM, tetap sama pada perbankan syariah. Sutan Remi Sjahdeini, Perbankan Islam dan Kedudukannya dalam Tata Hukum Perbankan Indonesia, Yayasan Adikarya IKAPI and Ford Foundation, Jakarta, 2005, hlm. 175-180
} 
Inilah prinsip yang dulu dikenal dengan sebutan CAMELS, yang merupakan kepanjangan dari capital (permodalan), asset quality (kualitas aset), management (manajemen), earning (rentabilitas), liquidity (likuiditas) dan sensitivity to market risk (sensitivitas terhadap risiko pasar). ${ }^{18}$ Namun, dalam perkembangannya kemudian, berbagai tantangan dan dinamika industri keuangan dengan berbagai transaksi yang ada di dalamnya menghendaki pendekatan yang lebih sempurna, yang dipandang lebih mampu mengantisipasi berbagai potensi kerusakan industri jasa keuangan. Maka prinsip tersebut kemudian dirubah dengan penggunaan pendekatan risiko (Risk-based Bank Rating), dengan instrumen yang lebih komprehensif. ${ }^{19}$ Meski demikian, berbagai indikator, antara lain FDR dan NPF di atas tetap merupakan bagian dari prinsip Risk-based Bank Rating ini.

Hal terkait dengan kesehatan pengelolaan dana inilah yang juga dengan jelas ditegaskan oleh peraturan perundang-undangan yang ada. ${ }^{20}$ Maka, dalam rangka menegakkan berbagai prinsip kehati-hatian atau prudensial tersebut, perbankan syariah harus menerapkan hal yang sama sebagaimana yang diterapkan dalam perbankan konvensional. Tuntutan dari implementasi prinsip ini akan berujung pada adanya ketentuan-ketentuan yang lebih tegas dalam berbagai hubungan antara perbankan dan nasabah. Misalnya saja, hal ini akan memberikan efek langsung dalam pembiayaan di mana keberadaan collateral atau jaminan menjadi hal yang diprioritaskan. Terkait jaminan ini, sebagaimana nanti akan dijelaskan lebih lanjut, telah menjadi permasalahan yang relatif kompleks pada perbankan syariah.

\section{Urgensi atas Sinergi Prinsip- Prinsip Syariah dan Regulasi Prudensial dalam Perbankan Syariah di Indonesia}

Dikarenakan pengaturan aspek prudensial dari perbankan yang ada merupakan formulasi yang pada awalnya dirancang dan didisain untuk perbankan konvensional, maka dapat saja terjadi berbagai benturan antara prinsip-prinsip

\footnotetext{
18 (Pasal 3 Peraturan Bank Indonesia Nomor: 6/10/PBI/2004 tentang Sistem Penilaian Tingkat Kesehatan Bank Umum). Lihat juga penjelasan tentang tingkat penilaian kesehatan bank yang merujuk pada CAMEL, yang dengan ini kemudian dapat ditetapkan dalam kuantifikasi yang rentangnya dari 0-100 kredit. Rachmadi Usman, Aspek-Aspek. Hukum Perbankan di Indonesia, Gramedia, Jakarta, 2001, hlm. 130-131

19 Peraturan Otoritas Jasa Keuangan Nomor 4 / Pojk.03/2016 tentang Penilaian Tingkat Kesehatan Bank Umum) Pasal 2-3

${ }^{20}$ Undang-Undang No. 21 Tahun 2008 tentang Perbankan Syariah Bagian Kedua Prinsip Kehati-hatian Pasal 35 ayat (1)
} 
dalam prudensial dengan prinsip dalam kepatuhan syariah. Berdasarkan analisa dan pencermatan yang dilakukan penulis, terdapat beberapa aspek yang dipandang potensial untuk menimbulkan konflik antara regulasi terkait prudensial dengan regulasi terkait kepatuhan syariah. Di bawah ini disajikan beberapa aspek yang dimaksud:

Pertama, Adanya keharusan jaminan pada semua bentuk pembiayaan. Telah dipaparkan dengan jelas di atas, untuk melakukan pembiayaan haruslah terpenuhi kelayakan yang dinilai dengan berdasarkan prinsip 5C. Namun, hal yang sangat menyulitkan di sini adalah adanya kelayakan yang dinilai dengan persyaratan collateral atau agunan sebagai jaminan.

Perbankan syariah di Indonesia, dan juga di berbagai negara di dunia ini, memiliki variasi produk yang hampir sama. Ialah bahwa terdapat beberapa produk, khususnya pembiayaan dengan landasan kontrak yang bersifat kerjasama. Kontrak atau akad ini merupkan aqad isytirak, ialah akad yang mendasarkan pada saling adanya partisipasi kedua belah pihak. Yang masuk dalam jenis akad isytirak ini adalah adalah akad musyarakah dan mudharabah, yang keduanya merupakan akad berbasis bagi hasil. Akad musyarakah adalah akad di mana dua pihak atau lebih bersepakat untuk menjalankan suatu usaha dengan jalan perkongsian, sedangkan akad mudharabah adalah akad antara dua pihak atau lebih di mana salah satu pihak sebagai pengelola modal dan pihak lainnya sebagai penyedia dana. Kedua akad tersebut jika diletakkan dalam konteks aplikasinya tentu tidak sederhana. Letak kesulitan dalam hal ini adalah karena akad yang berbasis kerjasama, khususnya mudharabah dan musyarakah pada asalnya menurut hukum Islam tidak memerlukan agunan. ${ }^{21}$

Perkembangan konteks permasalahan transaksi keuangan hari ini jauh berbeda jika dibandingkan dengan zaman dahulu ketika kepercayaan antar orang atau antar pihak masih sangat tinggi, sehingga mendorong adanya suatu bentuk pengamanan pembiayaan dengan adanya agunan. Hal ini akan lebih bermasalah

${ }^{21}$ Fatwa Dewan Syari'ah Nasional Nomor 07/DSN-MUI/IV/2000 tentang Pembiayaan Mudharabah (Qiradh), bagian Ketentuan Pembiayaan No. 7, yang berbunyi, "Pada prinsipnya, dalam pembiayaan mudharabah tidak ada jaminan, namun agar mudharib tidak melakukan penyimpangan, LKS dapat meminta jaminan dari mudharib atau pihak ketiga.” LKS dimaksud adalah Lembaga Keuangan Syariah (pen). 
karena dalam aplikasi penerapan agunan, landasan yuridis yang digunakan adalah Undang-Undang Republik Indonesia Nomor 42 Tahun 1999 tentang Jaminan Fidusia dan Undang-Undang Republik Indonesia Nomor 4 Tahun 1996 tentang Hak Tanggungan atas Tanah Beserta Benda-Benda yang Berkaitan dengan Tanah.

Hal yang menarik untuk dicermati adalah bahwa semua bentuk pembiayaan pada lembaga perbankan, sebagaimana tuntutan dari prinsip prudensial di atas, haruslah diikat dengan adanya jaminan yang didasarkan pada dua undangundang tersebut. Padahal, secara konstruksi yuridis, kedua jaminan tersebut dirancang untuk pengamanan transaksi utang-piutang. ${ }^{22}$ Dalam konteks perbankan syariah, hal ini berarti meletakkan akad syariah tersebut setara dengan penjanjian utang-piutang, bukannya bentuk perjanjian yang lain, karena fidusia dan hak tanggungan hanya diterapkan untuk perjanjian utang-piutang. Jelas ini telah mendistorsi sifat dasar akad yang melandasinya, di mana pada dasarnya akad yang digunakan adalah kerjasama atau perkongsian, namun kemudian dipaksakan untuk dianggap sebagai utang-piutang.

Kedua, memandang nasabah dengan kecurigaan. Memang dalam teorinya, bahwa prinsip KYC (Know Your Customer) bukanlah suatu bentuk kecurigaan, namun, dalam implementasinya hal ini akan sangat mudah bergeser pada kecurigaan. Pada dasarnya, dan memang seharusnya, hal ini tidak boleh berbenturan dengan asas praduga tidak bersalah, atau yang disebut dengan doktrin presumption of innocence, suatu doktrin yang menyatakan bahwa orang tidak dapat dianggap melakukan suatu kesalahan sebelum ada bukti yang menunjukkannya. ${ }^{23}$ Sejalan dengan asas praduga tidak bersalah ini, syariah Islam memiliki penegasan yang sejalan, ialah larangan untuk melakukan su'u al-dzan (prasangka buruk). ${ }^{24}$ Wajarlah jika perilaku berprasangka buruk dikecam dalam al-Qur'an sebagai sebuah dosa. Sedangkan,

${ }^{22}$ Hal ini dapat dicermati dari Undang-Undang No. 42 Tahun 1999 tentang Jaminan Fidusia. Di mana konstruksi hukumnya akan menjadi berbeda dengan dengan akad syariah. Karena dalam Pasal 1 dinyatakan bahwa fidusia sudah mengalihkan kepemilikan (ayat 1) hubungan hukumny adalah utang-piutang (ayat 2) dan kedudukan para pihak sebagai kreditor (ayat 9) dan debitor (ayat 10). Demikian halya dengan Undang-Undang No. 4 Tahun 1996 entang Hak Tanggungan Atas Tanah Beserta Benda-Benda Yang Berkaitan Dengan Tanah. Pasal 1 dinyatakan bahwa hubungan hukumnya adalah hutang-piutang, sebagaimana pada ayat (1), dan bahwa para pihak sebagai kreditur (ayat 2) dan debitur (ayat 3)

${ }^{23}$ International Covenant on Civil and Political Rights. Adopted by the General Assembly of the United Nations on 19 December 1966. Pasal 14 ayat (2). Diakses dari https://treaties.un.org/doc/publication/ Diakses pada 6 Desember 2018.

${ }^{24}$ Prasangka buruk adalah sebuah perbuatan tercela, yang dikatakan sebagai perboatan itsm, yang maknanya adalah dosa. (QS. Al-Hujurat: 12). 
implementasi dari KYC dalam praktik yang ada sangat rawan untuk bersinggungan dengan masalah ini. Agak sulit ditarik garis pembeda antara menggali informasi dengan kecurigaan. Karena ini masalah seperti ini harus berada dalam pengawalan yang ketat terkait dengan proses, pendekatan, dan mekanismenya.

Ketiga, sistem penagihan. Debt collecting atau penagihan hutang adalah hal penting dalam konteks menjaga agar perbankan tetap sehat (prudent). Memang secara teoretis, penagihan hutang adalah hal yang wajar, dan itu sekaligus merupakan konsekuensi logis dari adanya keterlambatan nasabah dalam membayar cicilan atau hutang sesuai dengan saat pembayaran yang telah disepakati. Namun, dalam implementasinya, penagihan hutang dapat menjurus pada tindakan yang menyimpang. Sebagaimana terjadi beberapa waktu yang lalu di mana petugas debt collecting Citibank akhirnya harus menghadapi tuntutan hukum dikarenakan tindakan yang sudah di luar batas kewajaran. Debt collector dari bank tersebut melakukan intimidasi yang berujung pada kematian nasabah. ${ }^{25}$ Memang secara baku, dalam syariah Islam tidak ada konsep praktis tentang penagihan hutang, namun prinsip syariah mengajarkan bahwa sebaik-baik orang yang berhutang adalah yang terbaik dalam mengembalikan uang yang dihutangnya tersebut. ${ }^{26}$ Di antara cara terbaik itu adalah tidak mempersulit kreditur jika menagihnya. Akan tetapi di sisi lain, Islam mengajarkan cara yang persuasif dalam menagih hutang, dan jika memang tidak memungkinkan, maka akan dilakukan ekskusi terhadap aset yang menjadi kolateral. Jelas, sangat nampak bahwa intimidasi tidak dapat dilakukan bagi nasabah yang mengalami kesulitan untuk mengangsur pelunasan hutangnya.

Bahkan, dalam skema yang ideal, bank syariah menganjurkan untuk melakukan tindakan dengan tujuan menolong. Dalam hal ini bank syariah sudah menyediakan sebuah produk yang bernama qardh al-hasan, ${ }^{27}$ ialah produk berupa

${ }^{25}$ Kasus Citibank adalah sebua tragedi debt collecting pada industri perbankan. Inilah Kronologi Kematian Nasabah Citibank, dalam https://nasional.republika.co.id/berita/ nasional/hukum/11/04/06/lj84g3-inilahkronologi-kematian-nasabah-citibank, akses 5 Mei 2018.

${ }^{26}$ Sesempurna-sempurna orang mukmin adalah yang paling baik dalam melunasi hutangnya. Dalam sebuah hadits yang diriwayatkan oleh Imam al-Bukhari, disebutkan فان من خيار الناس احنهم فضاء yang berarti "Di antara sebaik-baik manusia adalah yang paling baik dalam menunaikan hutang” (terj. Penulis). Shabih Bukhari, Kitab alIstigradh wa Ada' al-Duyun wa al-Hajr wa al-Taflis. Diambil dari aplikasi pencari hadits, http://library.islamweb.net/mainpage/ Akses 31 Oktober 2018

${ }^{27}$ Filosofi dari qardh al-hasan adalah adalah untuk menjadikan perbankan Islam (syariah) tetap memiliki misi sosial dan agama. Sehingga, tujuan dari Qardhul Hasan di antara yang utama adalah, "the objective is socio- 
peminjaman uang tanpa memberikan profit kepada bank, yang diperuntukkan khusus bagi orang yang tidak mampu secara ekonomi. Bahkan, dalam kondisi tertentu ketidakmampuan peminjam dapat menjadi alasan di mana uang tidak harus dikembalikan kepada bank.

Prinsip-prinsip aturan prudensial, di samping berbagai hal yang dinilai bertentangan dengan prinsip syariah tersebut di atas, juga jelas mengandung nilainilai yang sejalan dengan prinsip syariah. Nilai-nilai yang dimaksud meliputi; menepati waktu, amanah, transparansi, serta kerja keras. Menepati waktu sesuai yang dijanjikan adalah hal yang sangat esensial dalam berbagai skema perbankan, dan menurut prinsip syariah, menepati waktu adalah manifestasi dari penghargaan terhadap waktu yang mendapat penegasan sangat tinggi dalam alQur'an. $^{28}$ Di samping itu, menepati waktu juga merupakan bagian tidak terpisahkan dan sifat kesempurnaan iman seseorang, karena jika berbuat sebaliknya, ialah tidak menepati waktu yang telah disepakati, maka itu adalah sifat kemunafikan, karena hal itu kongruen dengan tidak menepati janji.

Paparan terkait dengan konflik antara aturan prinsip prudensial dengan kepatuhan syariah, jika dianalisa dengan seksama, terdapat celah untuk melakukan langkah atau upaya yang dinilai dapat mensinergikan tarikan dua kepentingan itu. Sehingga dari dua kepentingan yang dalam berbagai hal nampak saling melemahkan itu, dapat dirumuskan berbagai bentuk integrasi yang selain menjadi jalan tengah penyelesaian atau kompromi, juga dapat menjadi penguat atau nilai lebih dari perbankan syariah:

Pertama, tolok ukur keberhasilan. Tolok ukur keberhasilan dalam prinsip perbankan pada umumnya adalah indikator-indikator seperti NPF dan FDR sebagaimana dalam konsep CAMELS di atas. Indikator ini antara lain menunjukkan bahwa sebuah bank syariah akan diukur kesehatannya berdasarkan seberapa kecil pembiayaan bermasalah yang terjadi. Hal ini pada gilirannya akan mendorong pada berbagai upaya meminimalisir pembiayaan bermasalah dengan melakukan upaya berbagai macam cara untuk menagih pembiayaan yang

economic justice and equality" Sudin Haron, Islamic Banking: Rules and Regulations. Selangor, Pelanduk Publications, 1997. hlm. 78.

${ }^{28}$ Kearusan menepati apa saja sesuai dengan yang dijanjikan, termasuk waktu, ada dalam (QS. Al-Maidah: 1), yang artinya, "Hai orang-orang yang beriman, penuhilah akad-akad itu." 
bermasalah. Maka profesi yang kemudian muncul sebagai akibat dari hal ini adalah layanan jasa penagihan hutang (debt collector). Dalam pendekatan konvensional, parameter untuk melihat keberhasilan dalam konteks ini adalah terbayarnya uang atau angsuran. Sehingga apakah nasabah tersebut mengalami kesuksesan atau kegagalan dari pembiayaan yang diberikan untuk sebuah usaha di bidang ekonomi tertentu, bukanlah titik konsen utama. Hal penting untuk dipertimbangkan di sini bahwa ketika NPF dijadikan acuan dengan mengabaikan faktor kesuksesan yang lebih penting, ialah perbaikan kondisi ekonomi nasabah, maka keberadaan perbankan akan sangat negatif posisinya bagi pewujudan kesejahteraan masyarakat.

Ditinjau dari perspektif hukum Islam, tidak dapat dipungkiri, kelahiran dan keberadaan perbankan syariah ditopang oleh anjuran untuk melakukan tolongmenolong, ${ }^{29}$ karena itulah indikator kesehatan perbankan sebenarnya juga harus melibatkan indikator dampak pembiayaan terhadap kesuksesan para nasabah. Karena itu perlu ada penyempurnaan indikator kesehatan bank dengan melibatkan aspek sosial tersebut. Ungkapan lain yang dapat untuk mengkritisi hal ini adalah, apa gunanya jika NPF bagus tetapi keberadaan bank tidak menambah kesejahteraan masyarakat. Karenanya penting untuk ditambahkan dalam hal ini kriteria keberhasilan nasabah sebagai salah satu indikator dari kesehatan sebuah bank. Tidak sederhana memang, namun ini adalah aspek penting dari prinsip dan nilai syariah yang semestinya terakomodasi.

Kedua, legalitas atau keabsyahan. Ketentuan terkait kehati-hatian yang berupa pemenuhan terhadap prinsip 5C, ialah tentang collateral, mengandung permasalahan yang tidak sederhana. Keharusan adanya benda yang dijadikan jaminan telah menghadirkan sebuah dilemma tersendiri dalam konsep perbankan sebagai salah satu sarana penunjang terwujudnya kesejahteraan masyarakat. Di satu sisi, salah satu tujuan perbankan adalah meningkatkan perekonomian masyarakat, di mana orang-orang yang kesulitan mendapat akses pendanaan akan diakomodasi oleh pihak bank. Namun di sisi yang lain, bank harus menjaga

29 "Dan tolong-menolonglah kamu dalam (mengerjakan) kebajikan dan takwa, dan jangan tolong-menolong dalam berbuat dosa dan pelanggaran. Dan bertakwalah kamu kepada Allah, sesungguhnya Allah amat berat siksaNya. (QS. Al Maidah: 2) 
keamanan dana yang dimilikinya agar tidak hilang atau mengalami kerugian secara finansial.

Karena itulah maka dalam salah satu dari prinsip 5C tadi, ialah terkait dengan collateral, bank mengharuskan adanya benda yang menjadi jaminan. Sebagaimana yang berlaku selama ini, besaran jaminan haruslah memiliki nilai taksiran harga di atas dari jumlah uang yang dikeluarkan oleh bank. ${ }^{30}$ Keharusan ini bukan saja menjadi suatu hal yang memberatkan, di mana banyak orang yang tidak berkecukupan secara ekonomi tidak akan dapat memberikan barang jaminan. Karena itu, berbagai kelompok masyarakat yang memang lemah secara ekonomi justeru semakin jauh dari akases falilitas pembiayaan oleh bank.

Ketiga, layanan/tata kelola-etika. Standar pelayanan perbankan konvensional, etika penampilan dalam bekerja dibuat sedemikian rupa sehingga memberikan daya tarik kepada nasabah. Terkait dengan prosedur pelayanan, ada semacam mispersepsi bahwa yang namanya bank syariah harus mencerminkan ajaran agama dalam standar pelayanannya. Pada dataran ini sebenarnya masih wajar, karena memang demikianlah latar belakang historis dari lahirnya bank syariah. Namun, lebih jauh dari itu, bank syariah, yang karena harus mengekspresikan akhlak Islam, kemudian nampak dan memang mengesankan lebih ramah, atau lebih lunak. Hal ini ternyata kemudian melahirkan sebuah imej bahwa bank syariah semestinya lebih dapat memaafkan atas berbagai hal yang terjadi dengan nasabah. Dalam imej praktisnya adalah bahwa bank syariah semestinya dapat lebih lunak dalam hal jika nasabah mengalami kesulitan dalam mengembalikan uang yang telah diterima nasabah dalam bentuk pembiayaan atas suatu keperluan. Hal ini mestinya tidak benar jika dilihat dari pinsip-prinsip syariah sendiri.

Hal ini penting untuk diangkat bukan tanpa alasan. Dalam beberapa kasus, ada kecenderungan untuk menuntut bank syariah lebih toleran terhadap permasalahan nasabah, yang memang nasabah tertentu sudah pernah mengalami

${ }^{30}$ Besar nilai jaminan harus di atas nilai transaksi, biasanaya nilai taksasi diperhitungkan jumlah pembiayaan adalah sekitar 70-80\% dari harga taksiran barang jaminan. Atau jika dibalik, batasan minimal taksiran harga aset yang dijaminkan minimal $120 \%$ dari nilai hutang atau pembiayaan. Hal ini dapat disimpulkan antara lain dari: Peraturan Bank Indonesia Nomor 19/3/PBI/2017 Tentang Pinjaman Likuiditas Jangka Pendek Bagi Bank Umum Konvensional. 
permasalahan pada bank konvensional. Ketatnya ketentuan di bank konvensional menjadikan mereka untuk melirik ke bank syariah dengan anggapan akan lebih toleran. ${ }^{31}$ Memang, tidak dipungkiri bahwa religiusitas akan lebih membawa pasa asosiasi bahwa sesuatu lebih ramah, toleran dan lebih dapat memberikan permakluman, mengingat ajaran agama, dalam hal ini adalah prinsip syariah sangat menganjurkan pemberian maaf.

\section{Penutup}

Berdasarkan paparan di atas, dapat ditarik kesimpulan bahwa pertama, regulasi terkait prinsip prudensial dalam perbankan syariah adalah sama dengan regulasi yang ada pada perbankan konvensional. Artinya, dalam masalah ini, tidak ada perlakuan yang berbeda anatara bank konvensional dan bank syariah. Demikian halnya dengan implementasinya, bank syariah juga harus memberlakukan prosedur-prosedur dan langkah-langkah yang sama sebagaimana bank konvensional untuk memastikan bahwa prinsip-prinsip prudensial dijalankan. Misalnya saja, dalam pendekatan kepada nasabah yang mengadopsi pendekatan know your customer, dalam pembiayaan yang menerapkan kolateral secara ketat, serta, indikator keberhasilan dengan standar NPF.

Kedua, dikarenakan regulasi terkait prinsip-prinsip prudensial itu memang pada mulanya didisain untuk bank konvensional, maka berdasar analisis di atas, untuk mengupayakan terjadinya sinergi antara regulasi prinsip-prinsip prudensial dengan prinsip-prinsip syariah haruslah dilakukan penyesuaian (legal adjustment) oleh pemerintah ebagai regulator, dapat melalui mekanisme amandemen undangundang yang terkait, ialah Undang-Undang Republik Indonesia Nomor 42 Tahun 1999 tentang Jaminan Fidusia dan Undang-Undang Republik Indonesia Nomor 4 Tahun 1996 tentang Hak Tanggungan atas Tanah Beserta Benda-Benda yang Berkaitan dengan Tanah, atau pun juga dapat dilakukan dengan menerbitkan sebuah undang-undang yang khusus mengatur tentang penjaminan syariah. Hal

31 Dalam sebuah kasus yang pernah ditangani menunjukkan bahwa nasabah cenderung akan mencari peluang untuk melakukan kejahatan keuangan dengan melihat wilayah yang lebih lemah (rentan), dan dalam hal penyelenggaran jasa perbankan syariah masih lemah, maka bank syariah akan menjadi sasarannya. Sebagai ilustrasi bahwa kejahatan keuangan di perbankan Islam di Malaysia pun tidak luput dari kejahatan ini. R. Abdul Rahmanand I.S.Khair Anwar, 'Types of Fraud among Islamic Banksin Malaysia' dalam International Journal of Trade, Economics and Finance, Vol. 5, No. 2, April 2014. 
ini dilakukan dengan pembentukan model jaminan atas pembiayaan yang mengakomodasi berbagai jenis akad, mengakomodasi faktor keberhasilan nasabah dalam indikator NPF, serta, bentuk layanan yang yang dilakukan dengan tetap berpegang pada pendekatan yang kehati-hatian namun dilakukan sesuai dengan kaidah Islam.

Dikarenakan pada mulanya regulasi terkait dengan prinsip-prinsip prudensial dirancang dan diimplementasikan untuk perbankan konvensional, maka perlu diinisiasi regulasi prinsp-prinsip prudensial yang mengakomodasi kekhasan perbankan syariah. Hal ini dilakukan dengan memasukkan aspek sosial dan kesejahteraan nasabah dalam indikator suksesnya pembiayaan, serta kebebasan berkontrak (berakad) dalam prinsip muamalah (syariah), serta kaidahkaidah perilaku kesopanan dalam Islam.

\section{Daftar pustaka}

\section{Buku}

Chalil, Moenawar, Kelengkapan Tarikh Nabi Muhammad saw, Jakarta, Gema Insani Pers, 2001.

Haron, Sudin dan Bala Shanmugam, Islamic Banking System, Concepts and Applications, Pelanduk Publications, Selangor, 1997.

Haron, Sudin, Islamic Banking: Rules and Regulations. Selangor, Pelanduk Publications, 1997.

Hassa, Rusni, et al, A Comparative Analysis on Shariah Governance In Islamic Banking Accross Judisdiction, Institute for Shariah Research Academy (ISRA), Malaysia, 2013.

Sjahdeini, Sutan Remi, Perbankan Islam dan Kedudukannya dalam Tata Hukum Perbankan Indonesia, Yayasan Adikarya IKAPI and Ford Foundation, Jakarta, 2005.

Triyanta, Agus, Hukum Perbankan Syariah: Regulasi, Implementasi dan Formulasi Kepatuhannya Terhadap Prinsip-Prinsip Islam, Setara Press, Malang, 2016

Usman, Rachmadi, Aspek-Aspek Hukum Perbankan di Indonesia, Gramedia, Jakarta, 2001.

\section{Jurnal}

Abbadi, M Suleman dan Karsh, Sharif M. Abu, "Methods of Evaluating Credit Risk used by Commercial Banks in Palestin", International Research Journal of Finance and Economics, Issue 111 July, 2013. 
Rahman, R. Abdul and I.S.Khair Anwar, “Types of Fraud among Islamic Banksin Malaysia" dalam International Journal of Trade, Economics and Finance, Vol. 5, No. 2, April 2014.

Johannesen, Niels dan Gabriel Zucman, “The End Of Bank Secrecy? An Evaluation Of The G20 Tax Haven Crackdown", American Economic Journal: Economic Policy 2014, 6(1): 65 - 91

\section{Peraturan Perundang-Undangan/Instrumen Hukum Internasional}

Fatwa Dewan Syari'ah Nasional Nomor 07/DSN-MUI/IV/2000 tentang Pembiayaan Mudharabah (Qiradh).

International Covenant on Civil and Political Rights. Adopted by the General Assembly of the United Nations on 19 December 1966.

Peraturan Bank Indonesia Nomor 19/3/PBI/2017 tentang Pinjaman Likuiditas Jangka Pendek Bagi Bank Umum Konvensional.

Peraturan Bank Indonesia Nomor : 3/10/PBI/2001 tentang Penerapan Prinsip Mengenal Nasabah (Know Your Customer Principles)

Peraturan Bank Indonesia Nomor: 6/10/PBI/2004 tentang Sistem Penilaian Tingkat Kesehatan Bank Umum.

Peraturan Otoritas Jasa Keuangan Nomor 12/POJK.01/2017 tentang Penerapan Program Anti Pencucian Uang dan Pencegahan Pendanaan Terorisme di Sektor Jasa Keuangan.

Peraturan Otoritas Jasa Keuangan Nomor 12/POJK.01/2017 tentang Penerapan Program Anti Pencucian Uang dan Pencegahan Pendanaan Terorisme di Sektor Jasa Keuangan.

Peraturan Otoritas Jasa Keuangan Nomor 4 /Pojk.03/2016 tentang Penilaian Tingkat Kesehatan Bank Umum

Undang-Undang Nomor 21 Tahun 2008 tentang Perbankan Syariah (Tambahan Lembaran Negara Republik Indonesia Nomor 4867)

Undang-Undang Nomor 10 Tahun 1998 tentang Perbankan (Tambahan Lembaran Negara Republik Indonesia Nomor 3790)

Undang-Undang Nomor 19 Tahun 2008 tentang Surat Berharga Syariah Negara (SBSN) (Tambahan Lembaran Negara Republik Indonesia Nomor 4852)

Undang-Undang Nomor 4 Tahun 1996 tentang Hak Tanggungan Atas Tanah Beserta Benda-Benda Yang Berkaitan Dengan Tanah (Tambahan Lembaran

Negara Republik Indonesia Tahun 1996 Nomor 3632)

Undang-Undang Nomor 42 Tahun 1999 tentang Jaminan Fidusia (Tambahan Lembaran Negara Republik Indonesia Nomor 3889)

\section{Internet}

Featuring Black's Law Dictionary Free Online Legal Dictionary 2nd Ed, dalam https:/ / thelawdictionary.org/prudent/ diakses pada 25 April 2018. 
Minority Business Development Agency, US Department of Commerce, https:// www.mbda.gov/news/blog/2010/08/5-cs-credit-analysis akses pada 2 November 2018.

Inilah Kronologi Kematian Nasabah Citibank, dalam https://nasional.republika. co.id/berita/nasional/hukum/11/04/06/lj84g3-inilah-kronologikematian-nasabah-citibank, akses 5 Mei 2018 .

Shahih Bukhari, Kitab al-Istiqradh wa Ada' al-Duyun wa al-Hajr wa al-Taflis. Diambil dari aplikasi pencari hadits, http://library.islamweb.net/mainpage/ Akses 31 Oktober 2018 